\title{
Index of Persons
}

Abādir 'Umar al-Riḍā' 60

'Abd al-'Azīz b. Muḥammad al-Șanhājī, copyist $172,175-176,179$ n. 20, 181 Fig. 4, 181-185 + n. 42, 186, 195-196

šayh̆ 'Abd al-Ǧawād kabīr Ismā'īl b. alMuqrī, Harari learned man 70

šayh̆ 'Abdallāh al-Hararī 70

'Abd al-Karīm b. Șiddīq 66

'Abd al-Raḥmān Abū Bakr Šarīf 67 n. 32

'Abd al-Sattār al-Ḥalwajī 276

'Abdullāhi, emir of Harar 60

Abhayadeva $16+n \cdot 14,17+n .19+20$

Abū 'Abd Allāh Muḥammad b. Sa'īd alDūlāsī al-Būṣīrī see al-Būṣīrī

Abū al-'Abbās Aḥmad al-Anṣārī 280

Abū al-'Abbās Ạ̣mad b. Abī al-Qāsim alIdrīsī, known as al-Qaddūmī 194

Abū al-Fạ̣l 'lyāọ b. 'Iyāọ al-Yahsibī alSabtī 176, 177 Fig. 1

Abū al-Naṣr Sayf al-Dīn al-Ašrafī Qāytbāy 231

Abū al-Fạ̣l Aḥmad b. Muḥammad Ibn 'Aṭā Allāh al-Iskandarī 179

Abū al-Faḍl Muḥammad b. Ibrāhīm alTilimsānī 176,185

Muḥammad b. Aḥmad b. Muḥammad b. Aḥmad b. Muḥammad b. Muḥammad b. Abū Bakr Ibn Marzūq al-Tilimsānī 183 n.29

Abū Isḥāq Ibrāhīm b. Abī Bakr al-Tilimsānī 191

Abū al-Ḥasan 'Alī b. 'Abdallāh b. 'Abd alJabbār al-Ḥasanī al-Shādhilī 179 , 181 Fig. 3, 183

Abū al-Ḥasan Nūr al-Dīn 'Alī b. Nāṣir 67

Abū al-Qāsim b. Muḥammad al-Ṣayrafī 183

Abū Bakr Aḥmad bin 'Alī known as Ibn Waḥšiyya 242

Abū Bakr b. Muḥammad, emir of Harar 60

Abū Bakr Tābit (Sabit) 67

Abū Ḥāmid Muḥammad b. 'Alī b. 'Umar alSamarqandī 185 n. 44
Abū Midyan 194

Abū Iṣhāa Ibrāhīm b. Abū Bakr alTilimsānī Abū Šaḥma 85-85, 98

Abū 'Umar 293, 297

Abū Zayd al-Jādīrī (sic) 184 + n. 34, 192

Aḥmad al-Šāmī 59 n. 1

Aḥmad b. Ibrāhīm, imam 60

Ahmed Şeihâde 233 n. 34

al-Ahdal, Badr al-Dīn al-Ḥusayn b. alȘiddīq b. al-Ḥusayn b. 'Abd alRaḥmān 71 n. 43

Alexander the Great 238, 243

al-ḥāğğ 'Abd b. 'Abd al-Raḥmān b. ḥāğğ

'Āmid b. qāṭ Ibrāhīm b. qāt 'Alī, Harari copyist 69

'Alī b. Dawūd, emir of Harar 60,68

'Amdä Șəyon, Ethiopian king 60

Anastasius 313, 341

Aphou 134

Apollo of Bawit 134

Apollonius Rhodius 206

Archangel Michael 136

Sultan al-Ašraf Abū Nașr Qānșūh al-Ġawrī 231, 235, 236, 242

Sultan al-Ašrafī Abū Narṣ Qāytbāy 231, 233, 234

Aristotle $156+$ n. 23, 159 Fig. 7, 216, 223 310

Sirāj al-Dīn Abū Ḥafs 'Umar al-Bahādūrī 185

Baklmir Beg (Muḥammad bin Aḥmad) 234

Banti, Giorgio 62 n. 17

Baramus 135

ḥasan al-Bașrī 194

Beran, Mattheus 149,166 n. 38

Bishoi 135

Stephen of Bostra 314

Bourbon, Jean II de 257

'Dr. Bowdler of Byzantium' 210

Bricchetti, Luigi Robecchi 61

Buddha 3, 44 n. 18, 45 
al-Bukhārī 183, 186, 284

Bulbul 293-294

Burhān al-Dīn al-Biqā'ī 191 n. 60

al-Burnusī, Ibn Zarrūq 71 n. 43

al-Bușīīi, Muḥammad 67, 71 n. 43, 186, 190, 194

Cantacuzenus, John $308,328,340-343$

Cakreśvarī 12

Cedrenus, George 313, 330

Cephalas, Constantine 201-211

Christodorus of Coptus 202-203, 209 n. 32

Chrysostom, John 208, 310, 312-313

Clement of Alexandria 112

Colbert, Jean-Baptiste 255, 257, 261

Comnenus, Andronicus 312, 316, 327, 331, 335, 336 Tab. 2, $337+$ n. 94

Crux of Telč (Křǐž of Telč) 145-168

Cyril of Alexandria 341

al-Ḍaǧa'ī, Ibrāhīm b. Muḥammad 63 n. 23

al-Dānī 176 n. 10, 184

Damasus, Pope 117 n. 41

Daoyuan 道圓, monk 52

al-Dārimī 288

Democritus 217, 222

Desert Fathers 134-135

Dharmadāsa 27

'Imād al-Dīn 288

Muwaffaq al-Dīn 293

Nāṣir al-Dīn 288

al-Dimyāṭī, Nūr al-Dīn 71 n. 43

Diocletian 121

Drewes, Abraham Johannes 61

Sunbul Sinan Efendi 238 n. 39

Episcopopoulos, Antonios, scribe 342

Euclid 216 n. 3

Eusebius of Caesarea 111, 114-121, 313
al-Farnawī, Sultan Qāytbāy by Muḥammad b. Aḥmad 231, 233

Yahyā b. Aḥmad b. Muḥammad al-Anṣārī al-Fāsī 184

al-Fayyūmī, Šams al-Dīn Muḥammad 67 al-Fishtālī 192, 194

Frowinus of Cracow 152 Fig. 2

Galen 116 n. 38

al-Ġawrī, Al-Ašraf Qānșūh 231, 235, 236, 242

Gaza, John of 203

al-Ǧazūlī, Sulaymān 71 n. 43

Sultan 'Abd Allāh al-Ghālib 187, 194

Ghazāl 294

al-Ghazālī, Abū Ḥāmid 79, 99, 179, 181, 101, 185 n. 40, 194

de Gebir, Yça ('Īsā b. Jābir) 90-91, 94 + n. 83, 101

Glycas, Michael 328

Gregentius 331

Gregory of Nazianzus $203+n .8,209 n$. 32

Gregory of Nyssa 341

Ḩabbūba, emir of Harar 59

al-Ḥaddād, Muḥammad b. 'Alawī 71 n. 43 al-Ḥalabī, Sulaymān al-Mutanabbī $66 \mathrm{n}$. 31, 70, 227 n.25

Ḥāmid b. Șiddīq, Harari learned man 63 Hardy, Claude 255

walī Hāšim, Harari holy man 68 n. 34

Hāšim b. 'Abd al-'Aziz 59, 65, 67-71

Hāšim b. 'Alī b. Dawūd, emir of Harar 68

Sa'd al-Dīn Abū Sa'īd Musā'id b. Sārī b. Mas'ūd al-Hawārī 185

Tamr al-Harawī 185

vizir Abū 'Abd Allāh Muḥammad b. 'Abd al-Qādir b. Muhammad al-Sharîf alḤasanī 194

Heingarter, Conrad 247, 249-243, 261, 263 Fig. 1, 266, 267 Fig. 2, 269, 271273

Hemacandra, Jain scholar 9, 27, 30

Hesiodius 128 
Șafī al-dīn 'Abd al-'Azīz b. Sarāyā al-Ḥillī 190, 194

Homer 128, 206-207, 219 n. 8

Hugh of St Victor 264-265

Hus, Jan 148

Ibn al-Akfanī 231

Ibn al-'Arabī 194

Ibn al-Bannā' 179 + n. 20, 183 n. 31, 195196

Ibn 'Abd al-Hādī, scholar 279-280, 283

+ Fig. 3, 284-285, 286 Fig. 4, 287-

295 + Fig. 6, 296 Fig. 9, 297-299

Ibn Ḥanbal 292

Ibn Ḥarb 285

Ibn al-Nadīm 279

Ibn Marzūq see Muḥammad b. Aḥmad b.

Muḥammad b. Muḥammad b. abū

Bakr Ibn Marzūq

Ibn al-Ṣadr 288

Ibn Nāẓir al-Ṣāḥibīya 288

Ibn Qayyim al-Jawzīya 292

Ibn Rajab 292

Ibn Ṭabarzad 285

Ibn Taymīya 292

Ibn Ṭūlūn 297

Ibn Wahšìyya see Abū Bakr Aḥmad bin 'Alī 'Imād al-Dīn 288

Ibrāhīm Muḥammad Wazīr, Harari copyist $67+$ n. 32

Ibrāhīm b. 'Umar b. Sa'd b. 'Abdallāh, Harari copyist 69

Ibrāhīm 'Umar Sulaymān 70-71

'Īsā b. Jābir see de Gebir, Yça

Ismāî̉l b. Ibrāhīm 60

Aw 'Izzīn, Harari holy man (and graveyard called after him) 69

Jawhara 293-294

Jinaprabhasūri 16 n. 14, 22

John of Saxony 249, 263-265, 269, 270, 273

Kālaka 14,15+n. $11+$ n. 13
al-Khazrajī 177, 178 Fig. 2

Kolobos, John 135

Kṛșna 30

Kșitigarbha Bodhisattva 44

Kumārajīva 45

Lignères, Jean de 264

Lombard, Peter 153 Fig. 3

Mahāvīra 3-4. 32

Sultan Mahmud I $233+$ n. 34

al-Majūsī 179 n. 19

Muḥammad ibn Muhammad 235

Manasses, Constantinus 207

Mancebo de Arévalo 90-92

Sultan Aḥmad al-Manșūr 192

Magister, Leo 204, 205 n. 16

Ḍiyā' al-Dīn 'Abd Allāh b. Muḥammad alMakhzūmī 184

Malaxos, Manuel 338

Muhammad ibn 'Abd al-Malik 216 n. 3

al-Malik al-Ashraf 280

Ibn Mālik 183-184, 191, 192, 195

Muḥammad b. Abū Bakr b. 'Umar al-Mālikī 184

Ḍiyā' al-Dīn al-Maqdisī 293

Macarius, Desert Father 134-136

Mārīcī 43-44

Muḥammad b. Aḥmad b. Muḥammad b. Muḥammad b. abū Bakr Ibn Marzūq 183 n. 29, 186

Shams al-Dīn Abū 'Abd Allāh Muhammad b. 'Alī b. Ja'far al-Bilālī al-Mawșilī 185

Khalīl b. Ișḥāq b. Mūsā al-Mālikī al-Miṣrī 176, 191, 192, 195

Menander 128

Mənilək, Ethiopian king 60

Messahalah 260, 269

Moschus 206

Muhammad ibn 'Abd al-Malik 126 n. 3

Muhammad, the Prophet 62, 64, 277

Muḥammad b. 'Umar Šaw'ān 63 n. 23

Murs, des Jean 265 
al-Nasā'ī, Abū `Abd ar-Raḥmān Aḥmad ibn

Shưayb ibn Alī ibn Sīnān 288

al-Nawawī, Yaḥyā 63

Neapolitanus, Leontius 313, 314

Nicander 206

Nonnus of Panopolis 130, 202-204

Nordenfalk, Carl 119 n. 43

Nosidlo, Jan 165 n. 35, 166

Nūr b. Muğāhid, emir of Harar 60

Oppian of Apamea 206

Origen 112, $114+$ n. 32

Ōtani Kōzui 大谷光瑞 39

Páleč, Štěpán 148

Pamphilus 114 n. 32

Paul the Silentiary 202-203, 205 n. 17

Paul of Tamma 134

Paulitschke, Philipp 61, 62 n. 20

Periegetes, Dionysius 207

Planudes, Maximus 201, 204-206, 207

n. $24,208,209$ n. $33+$ n. $36,210-$ 211

Pindar 207

Pliny the Elder 120

Plutarch 204, 210 n. 39, 310,

Provataris, Manuel 335, 336 Tab. 2, 337

Ps. Alexander 225, 235, 238, 243

Ps. Aristotle 215-216+ n. 3, 222-223, 230-231, 243

Ps. Phocylides 206

Ptolemy $120-121+$ n. 47, 260, 269

Muḥammad b. 'Abd al-Qādir 188

Sultan Qāytbāy by the Mamlūk Yūsuf alMuhammadī 233, 234

al-Qayrawānī, Abū Muḥammad 'Abd Allāh

b. Abī Zayd 191, 192

'Alī b. 'Umar al-Qazwīnī 192 n. 74

Reminjo, Bray de 90-93, 96

Rhesinos 336 Tab. 2

Rosenthal, Franz 77 n. 9, 275
Rožmberk (Rosenberg) family 146 n. 2, $149+$ n. 10

R̦̣̦abhadāsa 12

Rufinus of Aquileia 151

Sacrobosco, Johannes de 264-265

al-Šāfi 'ī, Muḥammad b. Idrīs 71 n. 43

qāọī Șālị̣ 60

Abū 'Abd Allāh Muḥammad b. Yūsuf alḤasanī al-Sanūsī $191+$ n. 59

Samayasundara 23, 26 n. 43

Sarasvatī 30

Serapion of Antioch 112

al-Shāṭibī, Abū al-Qāsim al-Qāsim b.

Firrūh b. Khalak 176, 181, 184

Muḥammad al-Shaykh 194

Shenoute 129-130,133,136

Li Shunzi 李順子 51 n. 31

Siddhicandra, monk 26 n. 43

Sotakos 217

al-Suhaylī, 'Abd al-Raḥmān b. 'Abdallāh 71 n. 43

Syropoulos, Franciscus 335,336 Tab. 2

'Alī b. Abū Ṭālib 194

ḥāğğ Tawfiq 'Umar Baraso 69

Telč, Crux of see Crux of Telč

Thebanus, Simeon 308

Theodoret 312

Theocritus 206-207

Thucydides 128

Tišnov, Šimon of 148,156 n. 23

Tourianos 336 Tab. 2

Triclinius, Demetrius copyist 204 n. 13

al-Ṭulayțulī, Abū al-Ḥassan 'Ali ibn 'Isa 81, 101

Ibn Ṭūlūn 297

Tzetzes, John 207

Tzycandylis, Manuel 340

'Umar Sulaymān, copyist $70-71$ 
Václav z Vrbna (Wenceslas de Wrbna) 158, 159 Fig. 7

Vaișnava 30

Vajakuara 12

Versor, Jean 156-158, 159 Fig. 7, 168

Virgin Mary 136

Vok of Rožmberk, Petr 149 n. 10

Voragine, Jacobus de 150

al-Waqāy, Muḥammad 233, 234

Xenocrates of Ephesus 217, 222

Xingkong 性空, monk 52
Yaḥyā Nașrallāh 60

Yuḥannā (sic!) b. Māsawayh 179 n. 20

al-hāăğ Yūsuf 'Abd al-Raḥmān 70-72

Zakariyā' Ḥāmid 66

Zigabenus, Euthymius 312, 341

Laurinus de Znoima 153 Fig. 3

Stanislaus of Znojmo 148

Vavřinec of Znojmo 153 Fig. 3 
